\title{
Reconstructing Human Subsistence in the West Mouth (Niah Cave, Sarawak) Burial Series Using Stable Isotopes of Carbon
}

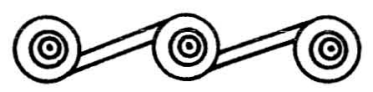

\author{
JOHN KRIGBAUM
}

THIS PAPER PRESENTS A PALAEODIETARY ANALYSIS using stable carbon isotopes of tooth enamel to explore diachronic patterns of human subsistence in the terminal Pleistocene and Holocene at Niah Cave (Sarawak, Malaysia). Niah's West Mouth has produced an outstanding archaeological assemblage (Barker et al. 2000, 2001, 2002a, 2002b, 2003; T. Harrisson 1957, 1959, 1972; Zuraina 1982) that "contains the longest stratified record of human occupation in Island Southeast Asia" (Bellwood 1997:172). Aside from early human remains of late Pleistocene context, most proper burials recovered from the West Mouth can be considered terminal Pleistocene or Holocene in age (Bellwood 1997; Brooks et al. 1979; B. Harrisson 1967; Krigbaum and Manser in prep.). The burial series provides a unique opportunity to address diachronic trends in pre-Neolithic and Neolithic human subsistence patterns in a single locale. Isotopic data presented below provide a fresh perspective for understanding prehistoric lifeways of foraging populations inhabiting tropical lowland settings in Southeast Asia, particularly with respect to how caves serve as a component of complex subsistence and settlement patterns (Anderson 1997).

\section{THE RESEARCH CONTEXT}

Surprisingly, little detailed work has been conducted on reconstructing prehistoric human subsistence in the lowland tropics of Southeast Asia. In part this is due to negative evidence in the record and the paucity of sites of appropriate age. Postglacial changes in topography and climate have greatly affected what evidence might exist for late Pleistocene human presence. Because the Sunda subcontinental shelf is so shallow, sea level transgression dramatically changed the configuration of land and sea, with rising sea levels submerging any habitation sites in coastal lowland settings (Dunn and Dunn 1977; Hanebuth et al. 2000; Sun et al. 
2000; Tjia 1980; Verstappen 1975, 1994). The late Pleistocene archaeological record after the Last Glacial Maximum is therefore biased toward moderately elevated lowland sites (ca. 100-300 m above sea level), inland from the shelf margin. This limits prehistoric subsistence reconstruction to archaeological contexts that are generally more terrestrial than coastal in character. This bias is compounded by the fact that archaeological assemblages in rainforest settings and lowland coastal environments such as peat swamp and mangrove are ephemeral in nature and such environments tend to support low densities of people (Bellwood 1990). Comparable prehistoric situations have been observed in low latitude regions of Sahul (Groube 1989; Pasveer et al. 2002; Pavlides and Gosden 1994), Africa (Brooks and Robertshaw 1990; Eggert 1992; Mercader 2003), and South America (Kipnis 1998; Roosevelt et al. 1996).

A central concern in rainforest prehistory is whether foragers, prior to the invention or adoption of agriculture, inhabited rainforest ecosystems independent of the coast and/or more seasonal monsoon areas (Bailey et al. 1989; Bailey and Headland 1991; Headland 1987; see also this volume: Barker, Barton). As Hutterer (1983) has noted, because of the extensive biomass in perhumid rainforests, humans would have been challenged with regard to mobility and resource procurement. Rainforest is difficult to navigate and foodstuffs are insecure, owing mainly to seasonal flux in fruiting. It is far more likely that foragers capitalized on forest resources via waterways and fringe habitats, accessing interior, terrestrial ecozones where caves such as Niah are found.

Prehistoric foragers inhabiting Southeast Asian rainforest had subsistence regimes often characterized as "broad spectrum" (Gorman 1971; Hutterer 1988; Krigbaum 2003). A wide variety of foodstuffs from hunted game to collected endemic plants and fruits was most certainly consumed (this volume: Barker, Barton, Paz), but the nature of modern human hunter-gatherer subsistence in tropical forest systems prior to and after the origins of agriculture is poorly understood based on current assessments of the archaeological record. Broad spectrum categories, however, do not improve understanding about the nuances of prehistoric human diet, be they cultural or ecological choices made in hunting and collecting food resources. Owing to preservational biases inherent in the archaeological record, diet is more often inferred based on indirect findings such as faunal and floral remains. Analysis of stable isotope ratios of carbon provides a means to infer human subsistence regimes against such important and complementary subsistence data recovered in the record.

\section{THE WEST MOUTH BURIAL SERIES}

Although other archaeologically significant cave mouths in the Niah massif were explored by Tom Harrisson and his Sarawak Museum colleagues during the 1950s and 1960s, excavation focused on the West Mouth deposits. The West Mouth stands ca. $20 \mathrm{~m}$ above lowland swamp and mixed dipterocarp forest. Archaeological "habitation" deposits up to $4 \mathrm{~m}$ in depth are mainly situated close to the mouth, in areas with ample afternoon sun and good shelter from the rain. Shallower "cemetery" deposits lie in the darker interior along the northern wall (Fig. 1; and this volume: Barker, Fig. 3). Over 370 trenches were excavated to varying 


\section{Niah Cave (West Mouth) Site Map}

+ Burial

-5 feet

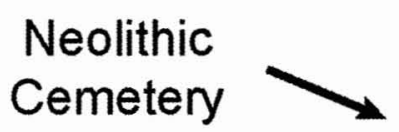<smiles>[12NH]</smiles>

\section{Pre-Neolithic} Habitation Area

Hell

Fig. 1. Niah Cave (West Mouth): the original trench layout, showing the three areas of concentrated archaeological excavation: the pre-Neolithic "habitation" area; the "Hell" deep sounding; and the Neolithic "cemetery."

depths by Tom Harrisson and Zuraina Majid, with the smaller units of the Hell deep sounding underlying the larger units in the habitation area, beginning at 96 in. below the original ground surface (Harrisson 1967; Zuraina 1982).

Remains of human activity, including faunal remains and pre-Neolithic burials, were found in the habitation area of the site, with some Neolithic burials associated with ceramics near the ground surface. The cemetery area produced an 
abundance of more superficial Neolithic-associated burial remains. The sheer size and temporal depth of this burial series, despite its fragmentary condition, make it the largest diachronic skeletal population in Island Southeast Asia.

In 1967 Barbara Harrisson outlined a classification system for the more than 170 burials that had been recovered at that time. These types correlate with preceramic and ceramic-associated modes of burial. The pre-Neolithic assemblage included primary flexed, seated, and secondary so-called "mutilation" burials. This latter classification term, as defined by Harrisson (1967:140), refers specifically to incomplete burial features rather than isolated elements. The ceramicassociated Neolithic remains consist mostly of primary "extended" burials (often in coffins), together with less frequent secondary burnt burials (often in ceramic vessels) and cremation burials. The only assigned human burial recovered in Hell Trench was the Deep Skull and associated postcranial remains, probably dating to ca. 43,000 B.P. (Barker et al. 2002a; Krigbaum et al. 2003; and see this volume: Barker; Gilbertson et al.).

Radiocarbon dating has been an important aspect to interpreting the Niah Cave record since the initial stages of excavation. Absolute ${ }^{14} \mathrm{C}$ dating on human bone was attempted by the Harrissons on several burial features (e.g., B. Harrisson 1967; T. Harrisson 1972, 1975) and by Brooks et al. (1979) on a subset of 30 burials. Given the complexities involved in securing accurate bone dates (Taylor 1992), all Niah Cave bone dates generated to date are deemed erroneous. Recent attempts to retrieve bone collagen from 28 burials sampled by Brooks et al. (1979) yielded negative results (Krigbaum 2001). For present purposes, cultural attribution of burials is simply based on burial context following Barbara Harrisson's classification. Different types may discriminate different prehistoric groups using the cave in prehistory, although this remains supposition. It is certain, however, that those burial types associated with ceramics are of Neolithic age.

The extraordinary amount of vertebrate and invertebrate remains recovered throughout the West Mouth sequence is testimony to the importance of broad spectrum subsistence hunting and collection typical of present-day huntergatherers in the region (Brosius 1991; Hutterer 1988). Animals such as the bearded pig (Sus barbatus), porcupine (Hystrix or Thecurus spp.), and various monkeys (Macaca fascicularis and Presbytis spp.) dominate the assemblage, along with freshwater snails. These remains span the Holocene transition from predominantly seasonal subtropical forest to more closed forest. Cranbrook's work on the Harrisson fauna identified 59 mammal species present in various levels of the habitation zone (Cranbrook 2000; Medway 1979). Plant food remains are considerably less abundant in the deposits, but certainly wild tubers, vegetables, fruits, and nuts factored into the overall subsistence regime (Barker et al. 2002a; this volume: Barker; Barton; Paz).

At times of low sea level, Niah Cave may have been quite distant (ca. $100 \mathrm{~km}$ ) from the South China Sea (see this volume: Gilbertson et al.), whereas by midHolocene times (ca. 6000 B.P.), the site was much closer to the coast. Subsistence trends therefore track environmental changes and local ecology in a fundamental way. Recovered invertebrate shell remains do show a slight increase in the number and abundance of marine and estuarine species in later Holocene levels, indicative of Niah Cave's close proximity to the coast at that time (Zuraina 1982; and this volume: Barker). 


\section{STABLE ISOTOPE RATIO ANALYSIS}

Major advances in bone chemistry have rapidly expanded the scope of palaeodiet research in the past decade. Stable isotope ratio analysis, in particular, is now well established in bioarchaeology (e.g., Ambrose and Katzenberg 2000; Krigbaum and Ambrose 2003). Such biogeochemical methods provide data with which to characterize diet in a particular sample or population. The old adage "you are what you eat" is true to the extent that dietary signals sequestered in most biological tissues (e.g., teeth, bone, hair, fingernails) and by-products (e.g., breath $\mathrm{CO}_{2}$ ) can be measured and quantified. Differences in stable carbon isotope ratios of plants and their consumer's tissues, such as bone or tooth enamel, thereby provide a dietary signature of the individual sampled that directly correlates with its diet (Ambrose 1993; Katzenberg 2000; Pate 1994; Schoeninger 1995; van der Merwe 1982).

The stable carbon isotope ratio $\left({ }^{13} \mathrm{C} /{ }^{12} \mathrm{C}\right)$ is determined for a given organic sample and compared to a standard of known abundance. With carbon, that standard is typically PDB, which refers to the Cretaceous belemnite from the Pee Dee Formation in South Carolina (Craig 1953), or its equivalent (since PDB has been exhausted). Oxygen's standard can be PDB or V-SMOW (or simply SMOW), referring to Vienna-Standard Mean Ocean Water (Gonfiantini 1978). Using delta notation $(\delta), \delta^{13} \mathrm{C}$ values are expressed in parts per thousand (\%) or "per mil." For a given sample $A$, its $\delta^{13} \mathrm{C}$ value is determined by comparing its ratio (where $R$ is ${ }^{13} \mathrm{C} /{ }^{12} \mathrm{C}$ or ${ }^{18} \mathrm{O} /{ }^{16} \mathrm{O}$ ) to that of a known standard, calculated as:

$$
\delta A(\%)=\left(R_{\text {sample }}-R_{\text {sample }} / R_{\text {std }}\right) \times 1000 \text { or } \quad\left(R_{\text {sample }} / R_{\text {std }}-1\right) \times 1000
$$

Lighter isotopes (e.g., ${ }^{12} \mathrm{C}$ ) react more quickly in chemical and physiological reactions than do their heavier counterparts (e.g., ${ }^{13} \mathrm{C}$ ). It is these differences in mass and their interplay during biochemical and metabolic processes that permit subtle differences to be measured by means of mass spectroscopy (Hoefs 1997). For example, ${ }^{12} \mathrm{C}$ is more mobile and reacts more quickly than ${ }^{13} \mathrm{C}$ as plants apply their carbon reserves to fix atmospheric $\mathrm{CO}_{2}$ during photosynthesis. Thus plants use more ${ }^{12} \mathrm{C}$ than ${ }^{13} \mathrm{C}$ during photosynthesis and are isotopically lighter (more negative in $\delta^{13} \mathrm{C}$ value) than atmospheric $\mathrm{CO}_{2}$, which has a modern $\delta^{13} \mathrm{C}$ value of $-7.8 \%$ ( $-6.5 \%$ in preindustrial times). Fractionation refers to the process whereby differences in isotopic abundance occur because of physiological and/or environmental processes. Such differences can be measured across various tissues within the same individual or across species, depending upon the types of research questions being raised.

Plants that fix atmospheric $\mathrm{CO}_{2}$ using a three-carbon molecule (phosphyoglycerate) follow the $\mathrm{C}_{3}$ (Calvin) photosynthetic pathway (all rainforest flora) and show a wide range of $\delta^{13} \mathrm{C}$ values, between $-20 \%$ and $-35 \%$, averaging $-27 \%$ (O'Leary 1981, 1988). In contrast, most arid-adapted grasses and some sedges use a four-carbon molecule (dicarboxylic acid) and follow the $\mathrm{C}_{4}$ (Hatch-Slack) photosynthetic pathway. $\mathrm{C}_{4}$ plants show less fractionation with atmospheric $\mathrm{CO}_{2}$ and exhibit a narrower range of $\delta^{13} \mathrm{C}$ values, between $-16 \%$ and $-7 \%$, averaging $-12.5 \%$ (O'Leary 1981,1988 ). $C_{3}$ plants include most trees, herbs, shrubs, and shady grasses. Common Southeast Asian $\mathrm{C}_{3}$ cultivars include rice, all tubers (e.g., 
yams), fruits, nuts, and most vegetables. $\mathrm{C}_{4}$ plants reflect adaptation to warm, water-stressed environments. East and Southeast Asian $\mathrm{C}_{4}$ cultigens include some millets, sorghum, Job's tears, and sugarcane.

Significant fractionation offset occurs between plants (primary producers) and the consumers (primary, secondary, etc.) that eat them. These consistent differences, or offsets, can be traced in biological tissues, resulting in a positive shift in $\delta^{13} \mathrm{C}$ value in the consumer tissue being analyzed: "you are what you eat" plus the offset value for the tissue being analyzed (Ambrose 1993). Whereas bone collagen has an offset value of $5 \%$, for tooth enamel it is $9 \%$ or fornivores and $14 \%$ for herbivores (Cerling and Harris 1999; Schwarcz 2000). Based on these figures, tooth enamel values would be expected to fall anywhere between $-17 \%$ and $-13 \%$ for a pure $\mathrm{C}_{3}$ vegetarian diet.

In most palaeodiet studies using stable isotopes derived from human bone, $\mathrm{C}_{3}$ vs. $\mathrm{C}_{4}$ dietary intake has been explored in contexts where $\mathrm{C}_{4}$ plants are involved in the adoption and diffusion of agricultural cereal crops (Schoeninger and Moore 1992). In the lowland rainforests of Southeast Asia, however, $C_{3}$ plants (and cultivars) are virtually ubiquitous, while $\mathrm{C}_{4}$ cereals are less likely to be adopted on account of the ever-wet conditions characteristic of the lower latitudes. The lack of a clear $\mathrm{C}_{3}$ vs. $\mathrm{C}_{4}$ scenario has dissuaded workers from applying isotopic techniques to areas dominated by $\mathrm{C}_{3}$ plants, such as Southeast Asia, where rice is assumed to be the principal domesticate. As Heaton (1999) and others (e.g., Ambrose 1993; Tieszen 1991) have noted, $C_{3}$ plant variation is underutilized in palaeodiet studies. $\delta^{13} \mathrm{C}$ plant variation is significant for $\mathrm{C}_{3}$ plants depending upon aspects of microhabitat (Heaton 1999). Plants grown in more open conditions are enriched in ${ }^{13} \mathrm{C}$ and have less negative $\delta^{13} \mathrm{C}$ values, in contrast with plants grown in more closed conditions, where there is extensive canopy cover (Krigbaum 2001). This is referred to as the "canopy effect" phenomenon. Average $\delta^{13} \mathrm{C}$ values of $-27 \%$ are present at canopy level, but ground-level plants and browse are considerably more negative, in the order of $-30 \%$ to -35\%o (Jackson et al. 1993; Krigbaum 2001, 2003; van der Merwe and Medina 1989, 1991; Vogel 1978). A vertical $\delta^{13} \mathrm{C}$ gradient exists (leaves, air, and so on) on account of decreased light levels (Broadmeadow and Griffiths 1993; Ehleringer et al. 1986) and recycled $\mathrm{CO}_{2}$ from the soil (Vogel 1978).

With respect to consumer tissues of interest (i.e., bone and teeth), two biological fractions are of interest: an organic, collagen fraction and an inorganic, mineral fraction referred to as hydroxyapatite or simply apatite. Both retain biological signals that isotopically correlate to overall diet. Mature bone tends to reflect a greater averaging effect due to the continuous nature of bone turnover and bone maintenance processes throughout adulthood. However, bone collagen is often degraded and difficult - if not impossible - to extract from remains recovered from hot and humid tropical contexts (Ambrose 1990; Ambrose and Norr 1992; Krigbaum 2001; Pate 1997). Under such conditions, bone mineral too is susceptible to postmortem diagenesis (Lee-Thorp 2000; Schoeninger et al. 1989). Tooth enamel, on the other hand, consists mainly of an inorganic fraction and is very resistant to postmortem alteration. It is the biological material of choice in palaeontological isotope studies because of its intrinsic physical properties and the structure of its hydroxyapatite crystal lattice (Wang and Cerling 1994). The biological signal in tooth enamel provides an accurate dietary signature during the 
time of enamel formation for the individual sampled. Third molars, being the last to form in the human dentition, tend to be highly variable in terms of development. Enamel formation may commence anywhere between 7 and 13 years of age, with crown completion occurring typically in the mid to late teens (Hillson 1996). Thus, although biased toward what might be considered a subadult diet, tooth enamel provides the best material in the lowland tropics to predict overall adult diet for individual remains. Data derived from such materials may then be interpreted against isotopic data derived both from modern plants and animals and from fauna from the archaeological record.

\section{MATERIALS AND METHODS}

Fifty human molars from different adult individuals buried at Niah were analyzed for stable isotopes, 43 from burial features with good context information (Table 1). Of these, 15 are from pre-Neolithic contexts, while 28 have Neolithic associations/features. Most of the Neolithic remains sampled are from the interior cemetery, while all pre-Neolithic remains are from the habitation portion of the site (Fig. 1). All disturbed/random remains sampled were recovered from the habitation area.

The external surfaces of teeth were cleaned with a Dremel tool. The cleaned enamel was ground and the enamel powder was oxidized in a 2 percent bleach solution $(\mathrm{NaOHCl})$. Oxidation of the sample was followed by pretreatment with $0.1 \mathrm{M}$ acetic acid. About $50-70 \mathrm{mg}$ of pretreated enamel powder was then hydrolized with 100 percent phosphoric acid $\left(\mathrm{H}_{3} \mathrm{PO}_{4}\right)$ in sealed reaction vessels for two hours at $90^{\circ} \mathrm{C}$. Evolved $\mathrm{CO}_{2}$ was passed through a silver phosphate trap $\left(\mathrm{AgPO}_{4}\right)$ to remove evolved $\mathrm{H}_{2} \mathrm{~S}$ or $\mathrm{SO}_{2}$, and the resultant $\mathrm{CO}_{2}$ gas was collected by cryogenic distillation. Stable isotope ratios for carbon and oxygen were then measured on a Finnigan MAT 251 isotope ratio mass spectrometer at Yale University's Department of Geology and Geophysics. The precision of these analyses is less than $0.05 \%$ for carbon and about $0.2 \%$ for oxygen.

Table I. Niah Cave (West Mouth): Burials Sampled for Isotopic Analysis By Type, ${ }^{a}$ Sex, and Location.

\begin{tabular}{|c|c|c|c|c|c|c|c|}
\hline & \multirow[b]{2}{*}{ BURIAL TYPE } & \multirow[b]{2}{*}{$\mathrm{N}$} & \multicolumn{3}{|c|}{ SEX } & \multicolumn{2}{|c|}{ WEST MOUTH } \\
\hline & & & $\mathrm{M} / \mathrm{M}$ ? & $\mathrm{F} / \mathrm{F} ?$ & $?$ & HABITATION & CEMETERY \\
\hline \multirow[t]{4}{*}{ Pre-Neolithic burials } & Seated & 3 & 2 & 1 & 0 & 3 & 0 \\
\hline & Flexed & 7 & 2 & 3 & 2 & 7 & 0 \\
\hline & Mutilation & 5 & 1 & 3 & 1 & 4 & 1 \\
\hline & Subtotal & 15 & 5 & 7 & 3 & 14 & 1 \\
\hline \multirow[t]{4}{*}{ Neolithic burials } & Burnt & 4 & 2 & 1 & 1 & 0 & 4 \\
\hline & Cremated & 2 & 0 & 1 & 1 & 0 & 2 \\
\hline & $\begin{array}{l}\text { Extended } \\
\quad \text { (incl. multiple) }\end{array}$ & 22 & 7 & 12 & 3 & 1 & 21 \\
\hline & Subtotal & 28 & 9 & 14 & 5 & 1 & 27 \\
\hline Disturbed/random & & 7 & 0 & 0 & 7 & 7 & 0 \\
\hline Total & & 50 & 14 & 21 & 15 & 22 & 28 \\
\hline
\end{tabular}

${ }^{\mathrm{a}}$ Types are as classified by B. Harrisson (1967); see text for explanation. 


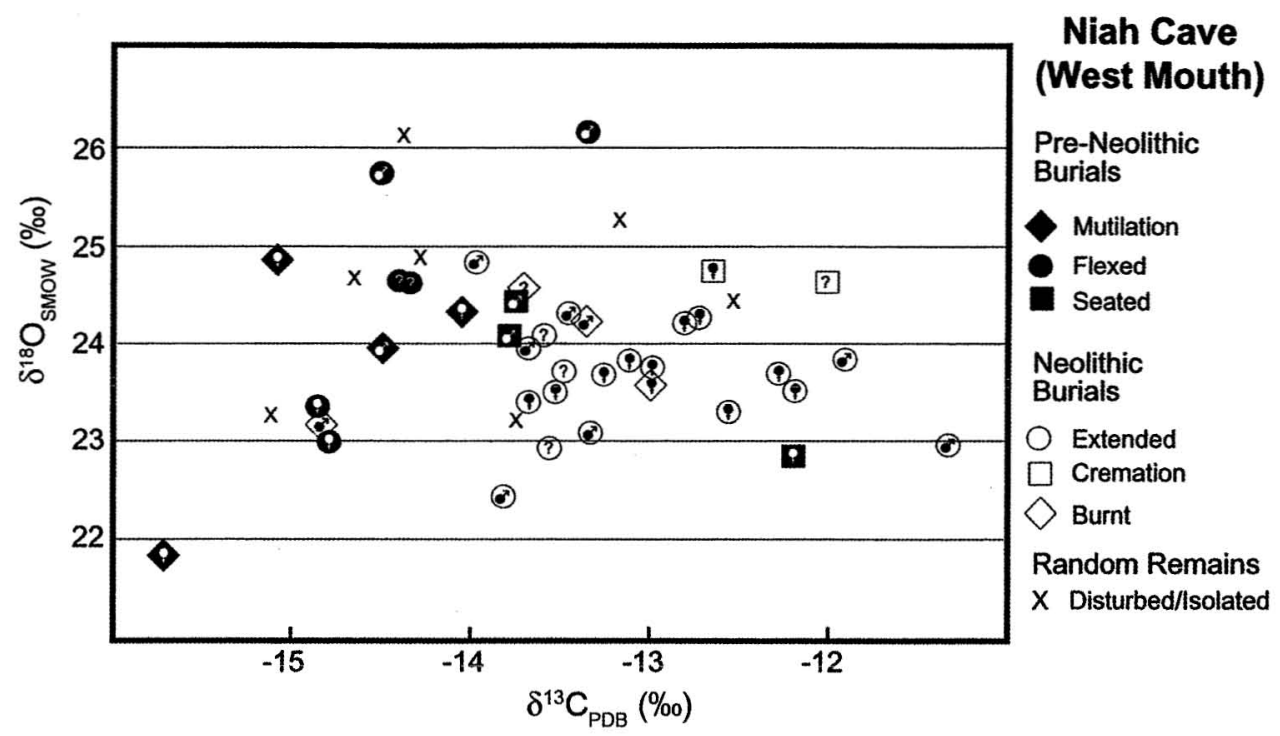

Fig. 2. Niah Cave (West Mouth): $\delta^{13} \mathrm{C}_{\mathrm{PDB}}$ and $\delta^{18} \mathrm{O}_{\mathrm{SMOw}}$ values (tooth enamel apatite) for preNeolithic and Neolithic human burials and disturbed/isolated remains. See text for explanation of burial terms.

\section{RESULTS}

$\delta^{13} \mathrm{C}$ and $\delta^{18} \mathrm{O}$ results for human remains sampled from the West Mouth are presented in Figure 2 for the six burial types and the disturbed/random burials. Table 2 presents the descriptive statistics for the burials sampled, and Figure 3 graphs the mean $\delta^{13} \mathrm{C}$ and $\delta^{18} \mathrm{O}$ values and standard deviation $(2 \sigma)$ by burial type.

Although this study focuses on the $\delta^{13} \mathrm{C}$ values as the primary data of interest in subsistence reconstruction, the $\delta^{18} \mathrm{O}$ values assist in examining $\delta^{13} \mathrm{C}$ variability

Table 2. Descriptive Statistics for Human $\delta^{13} \mathrm{C}$ and $\delta^{18} \mathrm{O}$ Results (Tooth Enamel Carbonate) from Niah Cave (West Mouth) by Burial Type ${ }^{a}$

\begin{tabular}{|c|c|c|c|c|c|c|}
\hline & & PRE-NEOLITHIC & & & NEOLITHIC & \\
\hline & MUTILATION & FLEXED & SEATED & EXTENDED & CREMATION & BURNT \\
\hline \multicolumn{7}{|l|}{$\delta^{13} \mathrm{C}$} \\
\hline $\mathrm{N}$ & 5 & 7 & 3 & 22 & 2 & 4 \\
\hline Mean & -14.9 & -14.4 & -13.3 & -13.2 & -12.3 & -13.7 \\
\hline SD & 0.63 & 0.52 & 0.91 & 0.82 & 0.46 & 0.79 \\
\hline Range & $\begin{array}{c}-15.7 \text { to } \\
-14.1\end{array}$ & $\begin{array}{c}-14.9 \text { to } \\
-13.4\end{array}$ & $\begin{array}{c}-13.8 \text { to } \\
-12.2\end{array}$ & $\begin{array}{c}-14.7 \text { to } \\
-11.3\end{array}$ & $\begin{array}{c}-12.7 \text { to } \\
-12.0\end{array}$ & $\begin{array}{r}-14.8 \text { to } \\
-13.0\end{array}$ \\
\hline \multicolumn{7}{|l|}{$\delta^{18} \mathrm{O}$} \\
\hline $\mathrm{N}$ & 5 & 7 & 3 & 22 & 2 & 4 \\
\hline Mean & 24.0 & 24.6 & 23.8 & 23.7 & 24.7 & 23.9 \\
\hline SD & 1.28 & 1.13 & 0.83 & 0.53 & 0.12 & 0.59 \\
\hline Range & 21.9 to & 23.0 to & 22.9 to & 22.5 to & 24.6 to & 23.2 to \\
\hline & 25.0 & 26.2 & 24.5 & 24.8 & 24.8 & 24.6 \\
\hline
\end{tabular}

${ }^{\text {a }}$ See text for explanation. 


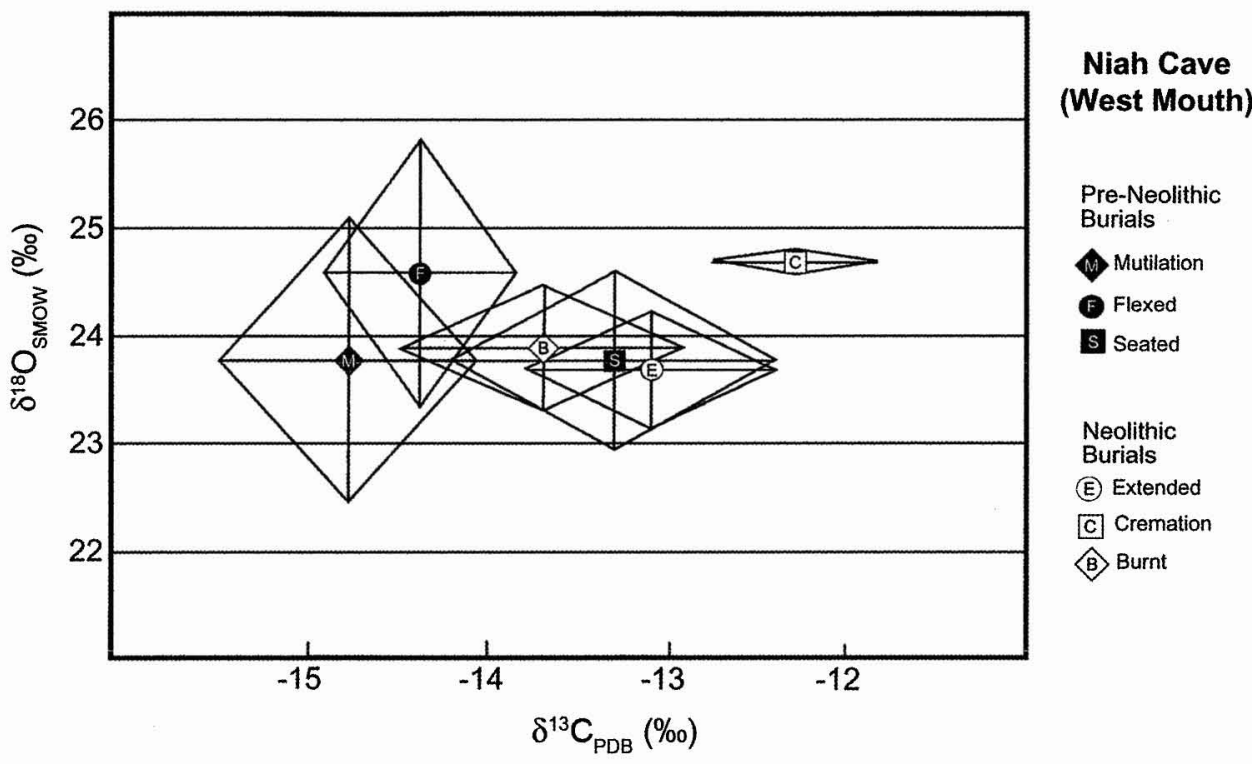

Fig. 3. Niah Cave (West Mouth): mean and standard deviation $(2 \sigma)$ for $\delta^{13} \mathrm{C}_{\mathrm{PDB}}$ and $\delta^{18} \mathrm{O}_{\mathrm{SMOW}}$ values (tooth enamel apatite) for pre-Neolithic and Neolithic human burials. See text for explanation of burial terms.

(Figs. 2 and 3). For $\delta^{13} \mathrm{C}$, the pre-Neolithic remains $(X=-14.5 \%$ ) are on average $1.3 \%$ more negative than the Neolithic remains $(X=-13.2 \%$ ). This difference is statistically significant by Student's $t$-test at the 0.01 level. Although the average difference may appear small, $\delta^{13} \mathrm{C}$ results demonstrate diachronic change in subsistence between these two time periods at Niah Cave. The $\delta^{13} \mathrm{C}$ range is $-15.7 \%$ o to $-12.2 \%$ for pre-Neolithic remains and $-14.8 \%$ o to $-11.3 \%$ for the Neolithic sample. Absolute difference in $\delta^{13} \mathrm{C}$ values for all human remains assayed is $4.4 \%$. Such a wide range of $\delta^{13} \mathrm{C}$ values is not only interesting for Niah, but encouraging for this and future studies assessing subsistence patterns using human tooth enamel apatite in $\mathrm{C}_{3}$-dominated ecosystems. $\delta^{18} \mathrm{O}$ values for pre-Neolithic remains are slightly more positive $(24.2 \%$ ) compared with the Neolithic remains $(23.8 \%$ ), although there is no statistical difference between the two groups.

Regarding specific burial types, the mutilation and flexed burial remains are more negative on average than the Neolithic sample, as presented above. Mutilation burials are fairly tightly clustered at the low end of $\delta^{13} \mathrm{C}$, while flexed burials are more varied in $\delta^{13} \mathrm{C}$, with some (Burial 172, $-13.4 \%$ ) approaching the extended/total Neolithic average. Taken together, the data suggest that preNeolithic subsistence at $\mathrm{Niah}$ was based on foraging in a variety of terrestrial habitats within closed forest. These findings are in reasonable accord with the emerging information from the geomorphology, palynology, archaeobotany, and archaeozoology for mosaic environments around Niah at the time of its occupation in the Pleistocene (this volume: Barker; Gilbertson et al.).

The seated burials, the final burial type assigned to the pre-Neolithic, have anomalous $\delta^{13} \mathrm{C}$ values for their supposed time period. They have a mean 
$(X=-13.3 \%)$ very similar to the mean for all Neolithic extended burials $(X=-13.2 \%)$. This probably represents a cultural distinction from mutilation and flexed burials that are near contemporaneous, although it may be that the single seated burial (Burial 141, $-12.2 \%$ ) is anomalous and the other two are simply slightly less negative than the others. More information regarding burial context is needed before such questions can be addressed with certainty. It appears, however, that the people of the seated burials had a diet routine that was different from that of the people in the other pre-Neolithic burials at Niah.

The largest Neolithic sample, the extended series, shows a wide range of $\delta^{13} \mathrm{C}$, with a relatively small error margin $(S D=0.53)$. Burnt and cremation burials also exhibit small ranges of deviation. However, one burnt and two or three extended burials are fairly negative and similar in $\delta^{13} \mathrm{C}$ values to many of the flexed and mutilation burials. Again, deciphering explanations for random burials is not possible at this stage, but it is likely that cultural factors and/or personal dietary preference are reflected in the $\delta^{13} \mathrm{C}$ differences. The two cremation burials have on average less negative $\delta^{13} \mathrm{C}$ values than other Neolithic remains, although several extended burials approach them. Burnt burials are temporally late in context at Niah, with one quite negative burial (Burial 103B, -14.8\%o) and three typical for the Neolithic sample.

\section{DISCUSSION AND CONCLUSION}

Broad-spectrum foraging at Niah for much of the late Pleistocene and Holocene is inferred by the wide variety of fauna recovered from the West Mouth deposits. Excavated remains demonstrate that virtually all represented vertebrate groups (except ubiquitous swiftlet and bat species) and shellfish remains were brought to the West Mouth by human agency (Cranbrook 2000; Medway 1959, $1960,1979)$, thus directly associated with the human occupation of and/or visitation to the site (e.g., T. Harrisson 1957, 1959, 1972; Medway 1979). Conclusions about variation and pattern of human subsistence trends over the course of preNeolithic and Neolithic occupation at West Mouth have therefore been minimal to date. Poor preservation of organic remains coupled with poor excavation methods in the initial stages of excavation (when most of the site was removed) leave provenence and feature context as well as temporal context in question. This does not make all excavated faunal remains useless; rather, novel approaches to their study remain to be implemented.

The stable carbon isotope data presented here are necessarily semi-quantitative and subject to interpretation, but represent the first diachronic investigation of prehistoric human subsistence in the rainforests of tropical Southeast Asia. Figure 4 summarizes the data presented above and allows new insights into pre-Neolithic broad-spectrum foraging patterns and Neolithic subsistence. The Neolithic period, of course, potentially reflects new subsistence regimes including some forms of food production and/or systematic collection (Bellwood 1992; Bellwood et al. 1992). A number of variables must be considered when interpreting these isotopic data, but without question the $\delta^{13} \mathrm{C}$ values reported directly reflect subsistence patterns of individuals tested, during the time of enamel formation-mostly in their older childhood, subadult years.

Neolithic presence in the mid-late Holocene (after ca. 3500 B.P.) is indicated 


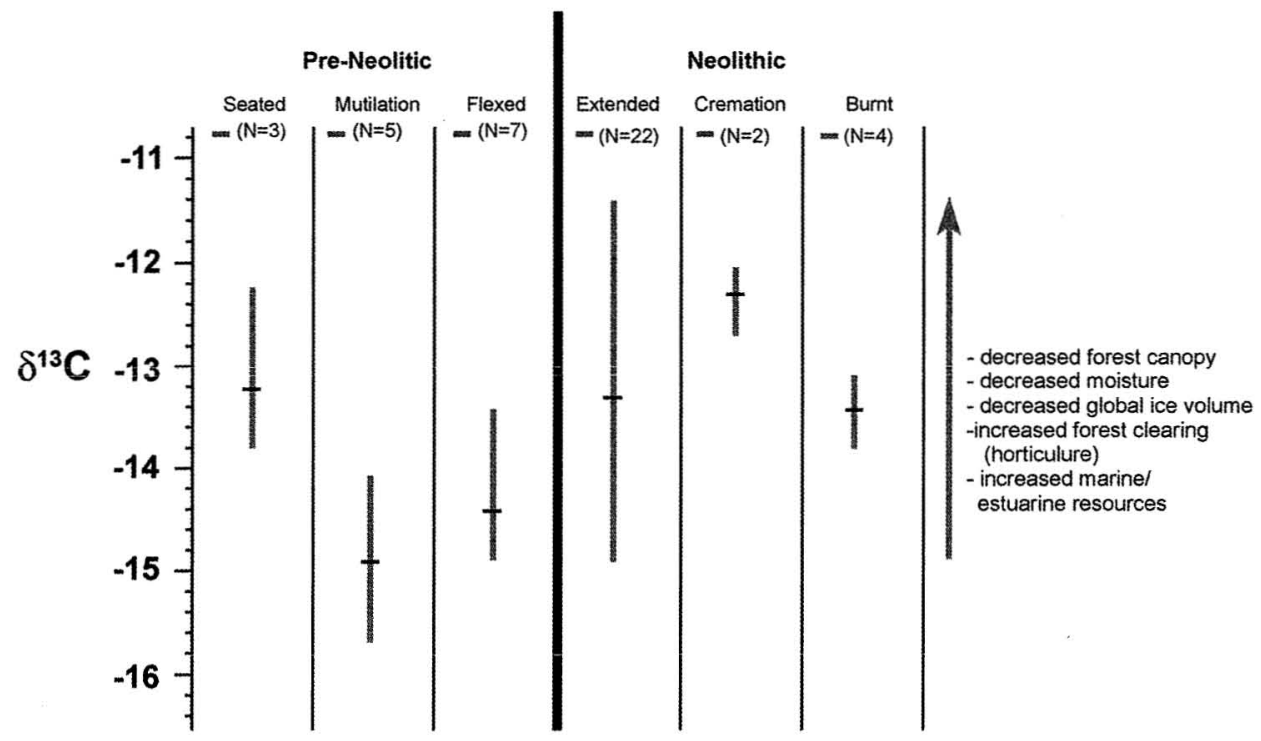

Fig. 4. Niah Cave (West Mouth): trends in $\delta^{13} \mathrm{C}_{\mathrm{PDB}}$ values for Pre-Neolithic and Neolithic human burials. See text for explanation of burial terms.

by extended, cremated, and burnt (jar) burials associated with elaborate pottery and polished stone tools. Whether these people reflect a new population of occupants (Austronesians) or simply a continuation of earlier representatives at the West Mouth remains an open question. A 4000 -year gap in accepted ${ }^{14} \mathrm{C}$ dates suggests a hiatus in cave use at the West Mouth, when sea levels may have been higher than present day and Niah Cave may have been more or less an isolated massif (though occupation may have continued in the Lobang Angus occupation; see this volume: Barker). This may well impact the understanding of biological and/or cultural influences reflected in Niah's Neolithic record (Krigbaum 2003).

The less negative $\delta^{13} \mathrm{C}$ values observed in Neolithic individuals compared with the pre-Neolithic sample are statistically significant. Ecological factors are unlikely to account for the shift, as the opposite trend would be expected in the improving climate of the Holocene: individuals subsisting on $\mathrm{C}_{3}$ foodstuffs in the more open and seasonal woodlands of the late Pleistocene would be expected to exhibit less negative values compared with foragers inhabiting the closed canopy forests of the Holocene. The lack of an ecological effect influencing $\delta^{13} \mathrm{C}$ values therefore suggests that anthropogenic factors are accountable for this shift, and that purposeful changes to the local environment influenced Neolithic diet. The trend could be influenced by several causal factors, all potentially interrelated.

The $\delta^{13} \mathrm{C}$ shift may reflect increased access to marine and estuarine resources, as noted in their increased frequency in more superficial levels of the site (Zuraina 1982), though further research is required to tease apart preservational and depositional constraints on these invertebrate materials. Also, it is unlikely that these would affect $\delta^{13} \mathrm{C}$ values to any marked degree, as coastal invertebrate species have been demonstrated to get their source carbon from terrestrial sources (Rodelli et al. 1984). Increased access to foods grown in more open settings 
("gaps") and/or the purposeful felling of tree stands would be consistent with a shift in $\delta^{13} \mathrm{C}$ values. This could have been coupled with the more systematic collection of plants and invertebrates from a greater diversity of ecozones.

However, the heterogeneity reflected in the Neolithic sample, especially among the extended burials, requires further analysis. The wide range of $\delta^{13} \mathrm{C}$ values suggests that the people who shared mortuary space and practice at Niah's West Mouth were characterized by a number of different dietary regimes. As Sather (1995) and others (e.g., Bellwood 1997; Harris 1989; Hutterer 1983) have proposed, foraging modes of subsistence probably remained in vogue among certain groups, while others may have been involved in food production to a greater degree. Further research on these data and continued analysis of the West Mouth burial series, as well as continued isotopic research on prehistoric and modern materials, will no doubt clarify the diverse roles that people played in northern Borneo during this period of increased complexity and interaction.

\section{ACKNOWLEDGMENTS}

This project would not be possible without the generous help and support of a number of people and institutions. First and foremost, the Sarawak Museum director and staff, in particular Ipoi Datan, Sanib Said, and Edmund Kurui for their longstanding interest in the application of isotopic geochemistry towards problems in Southeast Asian prehistory. Richard and Sheilagh Brooks and Bernardo Arriaza (Univ. Nevada, Las Vegas) are graciously acknowledged for their hospitality during my visits to Las Vegas. Comments by the reviewers and editorial changes by Graeme Barker, in particular, helped to clarify points raised in this paper. Funding was provided by pre-dissertation grants from Wenner-Gren and NSF.

\section{REFERENCES CITED}

Ambrose, Stanley H.

1990 Preparation and characterization of bone and tooth collagen for stable carbon and nitrogen isotope analysis. Journal of Archaeological Science 17:431-451.

1993 Isotopic analysis of paleodiets: Methodological and interpretive considerations, in Investigations of Ancient Human Tissue: Chemical Analyses in Anthropology: 59-130, ed. Mary K. Sandford. New York: Gordon and Breach.

Ambrose, Stanley H., and M. Anne Katzenberg, eds.

2000 Biogeochemical Approaches to Paleodietary Analysis. New York: Kluwer Academic Publishers.

Ambrose, Stanley H., and Lynette NorR

1992 On stable isotopic data and prehistoric subsistence in the Soconusco region. Current Anthropology 33:401-404.

Anderson, Douglas D.

1997 Cave archaeology in Southeast Asia. Geoarchaeology 12:607-638.

Bailey, Robert C., Genevieve Head, Mark Jenike, Bruce Owen, Robert Rechtman, and Elzbieta Zechenter

1989 Hunting and gathering in tropical rain forest; Is it possible? American Anthropologist 91:59-82.

Bailey, Robert C., and Thomas N. Headland

1991 The tropical rainforest: Is it a productive environment for human foragers? Human Ecology $19: 261-285$.

Barker, Graeme, Huw Barton, Paul Beavitt, Simon Chapman, Michael Derrick, Chris Doherty, Lucy Farr, David Gilbertson, Chris Hunt, Wayne Jarvis, John Krigbaum, Bernard Maloney, Sue Mclaren, Paul Pettitt, Brian Pyatt, Tim Reynolds, Garry Rushworth, and MARK STEPHENS 
2000 The Niah Caves Project: Preliminary report on the first (2000) season. Sarawak Museum Journal 55 (n.s. 76): 111-149.

Barker, Graeme, Dana Badang, Huw Barton, Paul Beavitt, Michael Bird, Patrick Daly, Chris Doherty, David Gilbertson, Ian Glover, Chris Hunt, Jessica Manser, Sue McLaren, Victor Paz, Brian Pyatt, Tim Reynolds, Jim Rose, Garry Rushworth, and Mark Stephens

2001 The Niah Cave Project: The second (2001) field season. Sarawak Museum Journal 56 (n.s. 77) :37-119.

Barker, Graeme, Huw Barton, Michael Bird, Franca Cole, Patrick Daly, David Gilbertson, Chris Hunt, John Krigbaum, Cynthia Lampert, Helen Lewis, Lindsay Lloyd-Smith, Jessica Manser, Sue Mclaren, Francesco Menotti, Victor Paz, Phil Piper, Brian Pyatt, Ryan Rabett, Tim Reynolds, Mark Stephens, Gill Thompson, Mark Trickett, and Paula WHITTAKER

$2002 a$ The Niah Cave Project: The third (2002) season of fieldwork. Sarawak Museum Journal 57 (n.s. 78) : 87-177.

Barker, Graeme, Huw Barton, Paul Beavitt, Michael Bird, Patrick Daly, David Gilbertson, Chris Hunt, John Krigbaum, Helen Lewis, Jessica Manser, Sue Mclaren, Victor Paz, Phil Piper, Brian Pyatt, Ryan Rabett, Tim Reynolds, Jim Rose, Garry Rushworth, and Mark Stephens

$2002 b$ Prehistoric foragers and farmers in Southeast Asia: Renewed investigations at Niah Cave, Sarawak. Proceedings of the Prehistoric Society 68:147-164.

Barker, Graeme, Huw Barton, Michael Bird, Franca Cole, Patrick Daly, Alan Dykes, Lucy Farr, David Gilbertson, Tom Higham, Chris Hunt, Stephanie Knight, Edmund Kurui, Helen Lewis, Lindsay Lloyd-Smith, Jessica Manser, Sue McLaren, Francesco Menotti, Phil Piper, Brian Pyatt, Ryan Rabett, Tim Reynolds, Jonathon Shimmin, Gill Thompson, and Mark Trickett

2003 The Niah Cave Project: The fourth (2003) season of fieldwork. Sarawak Museum Journal 58 (n.s. 79): 45-119.

Bellwood, Peter

1990 From late Pleistocene to early Holocene in Sundaland, in The World at 18,000 B.P., Vol. 2:255-263, ed. C. S. Gamble and O. Soffer. London: Unwin Hyman.

1992 The prehistory of Borneo. Borneo Research Bulletin 24:7-16.

1997 Prehistory of the Indo-Malaysian Archipelago, 2nd ed. Honolulu: University of Hawai' $i$ Press.

Bellwood, Peter, R. Gillespie, Gill Thompson, J. S. Vogel, I. W. Ardika, and Ipoi Datan

1992 New dates for prehistoric Asian rice. Asian Perspectives 32:37-60.

Broadmeadow, Mark S. J., and Howard Griffiths

1993 Carbon isotope discrimination and the coupling of $\mathrm{CO}_{2}$ fluxes within forest canopies, in Stable Isotopes and Plant Carbon-Water Relations: 109-129, ed. J. R. Ehleringer, A. E. Hall, and G. D. Farquhar. San Diego: Academic Press.

Brooks, Sheilagh T., Rodger Heglar, and Richard H. Brooks

1979 Radiocarbon dating and palaeoserology of a selected burial series from the Great Cave of Niah, Sarawak, Malaysia. Asian Perspectives 20:21-31.

Brooks, Alison S., and Peter Robertshaw

1990 The glacial maximum in tropical Africa: 22,000-12,000 B.P., in The World at 18,000 B.P., Vol. 2:121-169, ed. C. S. Gamble and O. Soffer. London: Unwin Hyman.

Brosius, J. Peter

1991 Foraging in tropical rainforests: The case of the Penan of Sarawak, East Malaysia. Human Ecology 19:123-150.

Cerling, Thure E., and John M. Harris

1999 Carbon isotope fractionation between diet and bioapatite in ungulate mammals and implications for ecological and paleoecological studies. Oecologia 120:347-363.

Craig, Harmon

1953 The geochemistry of the stable carbon isotopes. Geochimica et Cosmochimica Acta 3:5392.

Cranbrook, Earl of

2000 Northern Borneo environments of the past 40,000 years: Archaeozoological evidence. Sarawak Museum Journal 55 (n.s. 76) :61-109. 
Dunn, F. L., And D. F. DunN

1977 Maritime adaptations and exploitation of marine resources in Sundaic Southeast Asian prehistory. Modern Quaternary Research in Southeast Asia 3:1-28.

EgGert, MANFRED K. H.

1992 The Central African rainforest: Historical speculation and archaeological facts. World Archaeology $24: 1-24$.

Ehleringer, J. R., C. B. Field, Zhi-fang Lin, and Chun-yen Kuo

1986 Leaf carbon isotope and mineral composition in subtropical plants along an irradiance cline. Oecologia 70:520-526.

Gonfiantini, R.

1978 Standards for stable isotope measurements in natural compounds. Nature 271:534-536.

Gorman, Chester

1971 The Hoabinhian and after: Subsistence patterns in Southeast Asia during the late Pleistocene and early recent periods. World Archaeology 2(3):300-320.

Groube, Les

1989 The taming of natural forests: A model for late Pleistocene forest exploitation in New Guinea, in Foraging and Farming: The Evolution of Plant Exploitation: 292-304, ed. David R. Harris and Gordon C. Hillman. London: Unwin Hyman.

Hanebuth, Till, Karl Stattegger, and Pieter M. Grootes

2000 Rapid flooding of the Sunda Shelf: A late-Glacial sea-level record. Science 288:10331035.

HARRIS, DAVID R.

1989 An evolutionary continuum of people-plant interaction, in Foraging and Farming: The Evolution of Plant Exploitation: 11-26, ed. D. R. Harris and G. C. Hillman. London: Unwin Hyman.

HARrisSON, BARBARA

1967 A classification of Stone Age burials from Niah Great Cave, Sarawak. Sarawak Museum Journal 15 (n.s. 30-31): 126-200.

HARrisson, TOM

1957 The Great Cave of Niah: A preliminary report on Bornean prehistory. Man 57:161166.

1959 New archaeological and ethnological results from Niah Caves, Sarawak. Man 59:1-8.

1972 The prehistory of Borneo. Asian Perspectives 13:17-45.

1975 Early dates for "seated" burial and burial matting at Niah Caves, Sarawak (Borneo). Asian Perspectives 18:161-165.

Headland, Thomas N.

1987 The wild yam question: How well could independent hunter-gatherers live in a tropical rainforest ecosystem? Human Ecology 15:463-491.

Heaton, Tim H. E.

1999 Spatial, species, and temporal variations in the ${ }^{13} \mathrm{C} /{ }^{12} \mathrm{C}$ ratios of $\mathrm{C}_{3}$ plants: Implications for paleodiet studies. Journal of Archaeological Science 26:637-649.

Hillson, Simon

1996 Dental Anthropology. Cambridge: Cambridge University Press.

HoEfs, Jochen

1997 Stable Isotope Geochemistry, 4th ed. Berlin: Springer-Verlag.

HutTerer, Karl L.

1983 The natural and cultural history of Southeast Asian agriculture. Anthropos 78:169-212.

1988 The prehistory of the Asian rainforests, in People of the Tropical Rainforest: 63-72, ed. J. S. Denslow and C. Padoch. Berkeley: University of California Press.

Jackson, Paula C., Frederick C. Meinzer, Guillermo Goldstein, Noel M. Holbrook, Jaime Cavelier, and Fermin Rada

1993 Environmental and physiological influences on carbon isotope composition of gap and understory plants in a lowland tropical forest, in Stable Isotopes and Plant Carbon-Water Relations: 131-140, ed. J. R. Ehleringer, A. E. Hall, and G. D. Farquhar. 'San Diego: Academic Press. 
Katzenberg, M. AnNe

2000 Stable isotope analysis: A tool for studying past diet, demography, and life history, in Biological Anthropology of the Human Skeleton: 305-327, ed. M. A. Katzenberg and S. R. Saunders. New York: Wiley-Liss.

Kipnis, Renato

1998 Early hunter-gatherers in the Americas: Perspectives from central Brazil. Antiquity $72: 581-592$.

KRIGBAUM, JOHN

2001 Human Paleodiet in Tropical Southeast Asia: Isotopic Evidence from Niah Cave and Gua Cha. Ph.D. diss. New York University, New York.

2003 Neolithic subsistence patterns in northern Borneo reconstructed with stable carbon isotopes of enamel. Journal of Anthropological Archaeology 22:292-304.

Krigbaum, John, and Stanley H. Ambrose, eds.

2003 Bone chemistry in bioarchaeology. Journal of Anthropological Archaeology 22:191-304.

Krigbaum, John, and Jessica Manser

In prep. The West Mouth (Niah Cave, Sarawak) burial series, in Perak Man and Other Skeletons in Malaysia, ed. Zuraina Majid.

Krigbaum, John, Jessica Manser, Graeme Barker, Huw Barton, Michael Bird, Ipoi Datan,

David Gilbertson, Chris Hunt, Tim Reynolds, W. Sanders, and Chris Stringer

2003 The early human remains from Niah Cave's West Mouth (Sarawak, Malaysia). Unpublished paper. Paleoanthropology Society Annual Meeting, Tempe, AZ.

Lee-Thorp, Julia A.

2000 Preservation of biogenic carbon isotopic signals in Plio-Pleistocene bone and tooth mineral, in Biogeochemical Approaches to Paleodietary Analysis: 89-115, ed. S. H. Ambrose and M. A. Katzenberg. New York: Kluwer Academic Publishers.

MEDWAY, LORD

1959 Niah animal bone: II (1954-8). Sarawak Museum Journal 9 (n.s. 13-14) :151-163.

1960 Niah Shell-1954-8. Sarawak Museum Journal 9 (n.s. 13-14):368-379.

1979 The Niah excavations and an assessment of the impact of early man on mammals in Borneo. Asian Perspectives 20:51-69.

MERCADER, JULIO

2003 Foragers of the Congo: The early settlement of the Ituri Forest, in Under the Canopy: The Archaeology of Tropical Rainforests: 93-116, ed. J. Mercader. New Brunswick, NJ: Rutgers University Press.

O'Leary, Marion H.

1981 Carbon isotope fractionation in plants. Phytochemistry 20:553-567.

1988 Carbon isotopes in photosynthesis. BioScience 38:328-336.

Pasveer, Juliette M., Simon J. Clarke, and Gifford H. Miller

2002 Late Pleistocene human occupation of inland rainforest, Bird's Head, Papua. Archaeology in Oceania 37:92-95.

Pate, F. Donald

1994 Bone chemistry and paleodiet. Journal of Archaeological Method and Theory 1:161-209.

1997 Bone collagen diagenesis at Roonka Flat, South Australia: Implications for isotopic analysis. Archaeology in Oceania 32:170-175.

Pavlides, Christina, and Chris Gosden

1994 35,000-year-old sites in the rainforests of West New Britain, Papua New Guinea. Antiquity 68:604-610.

Rodelli, M. R., J. N. Gearing, P. J. Gearing, N. Marshall, and A. Sasekumar

1984 Stable isotope ratio as a tracer of mangrove carbon in Malaysian ecosystems. Oecologia $61: 326-333$.

Roosevelt, Anna C., M. Lima da Costa, C. Lopes Mochado, M. Michab, N. Mercier, H. Valladas, J. Feathers, W. Barnett, M. Imazio da Silveira, A. Henderson, J. Sliva, B. Chernoff, D. S. Reese, J. A. Holman, N. Toth, AND K. Schick

1996 Paleoindian cave dwellers in the Amazon: The peopling of the Americas. Science $272: 373-384$. 


\section{SATHER, ClifFord}

1995 Sea nomads and rainforest hunter-gatherers: Foraging adaptations in the Indo-Malaysian archipelago, in The Austronesians: Historical and Comparative Perspectives: 229-268, ed. P. Bellwood, J. J. Fox, and D. Tryon. Canberra: Australian National University, Research School of Pacific and Asian Studies, Department of Anthropology.

SCHOENINGer, MARgaret J.

1995 Stable isotope studies in human evolution. Evolutionary Anthropology 4:83-98.

Schoeninger, Margaret J., and Katherine Moore

1992 Bone stable isotope studies in archaeology. Journal of World Prehistory 6:247-296.

Schoeninger, Margaret J., Katherine M. Moore, Matthew L. Murray, and John D. KINGSTON

1989 Detection of bone preservation in archaeological and fossil samples. Applied Geochemistry $4: 281-292$.

SChwarCZ, Henry P.

2000 Some biochemical aspects of carbon isotopic paleodiet studies, in Biogeochemical Approaches to Paleodietary Analysis: 189-209, ed. S. H. Ambrose and M. A. Katzenberg. New York: Kluwer Academic Publishers.

Sun, Xianguun, Xu Li, Yunli Luo, and Xudong Chen

2000 The vegetation and climate at the last glaciation on the emerged continental shelf of the South China Sea. Palaeogeography, Palaeoclimatology, Palaeoecology 160:301-316.

TAYLOR, ROYAL ERviN

1992 Radiocarbon dating of bone: To collagen and beyond. In Radiocarbon after Four Decades: An Interdisciplinary Perspective: 375-402, ed. R. E. Taylor, A. Long, and R. S. Kra. New York: Springer-Verlag.

TIESZEN, LARRY L.

1991 Natural variations in the carbon isotope values of plants: Implications for archaeology, ecology and paleoecology. Journal of Archaeological Science 18:227-248.

TJIA, H. D.

1980 The Sunda Shelf, Southeast Asia. Zeitschrift fur Geomorphologie N.F. 24:405-427.

van der Merwe, Nikolaas J.

1982 Carbon isotopes, photosynthesis, and archaeology. American Scientist 70:596-606.

van der Merwe, Nikolaas J., and Ernesto Medina

1989 Photosynthesis and ${ }^{13} \mathrm{C} /{ }^{12} \mathrm{C}$ ratios in Amazonian rainforests. Geochimica et Cosmochimica Acta 53:1091-1094.

1991 The canopy effect, carbon isotope ratios and foodwebs in Amazonia. Journal of Archaeological Science 18:249-259.

Verstappen, Herman Th.

1975 On palaeoclimates and landform development in Malesia. Modern Quaternary Research in Southeast Asia 1:3-35.

1994 Climatic change and geomorphology in South and Southeast Asia. Geo-Eco-Trop $16: 101-147$.

Voget, J. C.

1978 Recycling of carbon in a forest environment. Oecologia Plantarum 13:89-94.

Wang, Yang, and Thure E. Cerling

1994 A model of fossil tooth and bone diagenesis: Implications for paleodiet reconstruction from stable isotopes. Palaeogeography, Palaeoclimatology, Palaeoecology 107:281-289.

Zuraina Majid

1982 The West Mouth, Niah, in the prehistory of Southeast Asia. Sarawak Museum Journal 31 (n.s. 52) : 1-200.

\section{ABSTRACT}

The human burial series from the West Mouth of Niah Cave (Sarawak) offers a unique opportunity to explore prehistoric subsistence patterns in lowland tropical rainforest. Over 200 primary and secondary burials, classified as pre-Neolithic 
and Neolithic, have been recovered since preliminary excavations began there a half-century ago. Stable isotope ratios of carbon $\left({ }^{13} \mathrm{C} /{ }^{12} \mathrm{C}\right.$, reported as $\delta^{13} \mathrm{C}$ values) derived from human tooth enamel provide a quantitative measure of individual food consumption during the time of enamel formation. Such data provide a robust and independent assessment of total diet that complements other subsistence information recovered from the archaeological record. West Mouth human tooth enamel examined shows a broad range of $\delta^{13} \mathrm{C}$ values $(-15.7 \%$ o to $-11.3 \%$ ), consistent with a $\mathrm{C}_{3}$-based subsistence regime as would be expected in rainforest habitats dominated by $\mathrm{C}_{3}$ vegetation. Pre-Neolithic individuals have more negative $\delta^{13} \mathrm{C}$ values on average $(N=15, \quad X=-14.3 \%)$ than Neolithic individuals sampled $(N=28$, $X=-13.1 \%$ ). This isotopic shift is statistically significant and suggests a fundamental change in human subsistence between the late Pleistocene/early Holocene and later Holocene inhabitants at Niah. Pre-Neolithic $\delta^{13} \mathrm{C}$ values suggest broad spectrum rainforest foraging, whereas less negative Neolithic $\delta^{13} \mathrm{C}$ values, on average, suggest a more coordinated regime of food production and/or collection. Studies of $\delta^{13} \mathrm{C}$ variation in rainforest habitats contribute to this interpretation, particularly with respect to the "canopy effect," whereby closed-canopy foraging predicts more negative $\delta^{13} \mathrm{C}$ values, while food resources consumed by exploiting more open settings (such as fields, gaps, and swamps) predict less negative $\delta^{13} \mathrm{C}$ values. These data have important implications for interpreting the nature of human subsistence in a rainforest setting prior to and after the potential adoption of agriculture by the inhabitants represented in the West Mouth burial series. KeYwords: Niah Cave, Southeast Asia, Borneo, prehistory, late Pleistocene, Holocene, Neolithic, bioarchaeology, palaeodiet, subsistence, carbon isotopes. 